Volume 19, Number 59 : June 1967 : Price Five Shillings

\title{
EDITORIAL ADVISORY BOARD
}

A. L. L. Baker, DSc(Eng), MICE, MIStructE

Professor of Concrete Structures and Technology, University of London, Imperial College of Science and Technology

W. F. Cassie, PhD, MS, FRSE, MICE, MIStructE

Professor of Civil Engineering, University of Newcastle upon Tyne

R. H. Evans, CBE, DSc, DèsSc, PhD, MICE, MIMechE, MIStructE

Professor of Civil Engineering, University of Leeds

T. W. Parker, MSc, PhD, FRIC

Director, The Agrement Board

A. D. Ross, BSc, PhD, FRSE, MICE

Professor of Ciril Engincering, University of London, King's College

R. E. Rowe, MA, ScD, AMICE

Director of Research and Development, Cement and Concrete Association

EDITOR AND SECRETARY TO THE BOARD

Anthony E. Brooks, BA

Designed, printed and published four times a year by the Cement and Concrete Association

Editorial Office: Wexham Springs, Slough, Bucks, Telephone: Fulmer 212, Telex: Advicret Slough 84352 


\section{Editorial comment}

IN THE DESIGN of a reinforced concrete structure one of the criteria governing the proportioning of members and the detailing of the reinforcing steel is the requirement that the width and distribution of cracks should be controlled within certain limits. In most codes of practice this particular criterion has usually been covered by limiting the permissible stress in the steel to a level which experience has shown to provide an acceptable control on cracking. However, with the continuing interest of the Comité Européen du Béton (C.E.B.) in its attempt to rationalize design procedures for reinforced concrete, new concepts of design have been propounded which require a rational treatment of the critical limit states governing the behaviour of reinforced concrete structures; cracking is one of these limit states. Further, in recent years, new reinforcing steels have been introduced which have a higher yield stress or proof stress and also have surface deformations rolled on to improve the bond characteristics; the crack control characteristics of these steels required definition.

For these reasons, Commission IVa of the C.E.B. surveyed the various theoretical solutions to the cracking phenomenon and the experimental data available at that time and, in its recommendations published in $1964^{(1)}$, suggested a crack control formula for use in design. Since the drafting of the recommendations, quite extensive research on this subject has been carried out on the Continent, in the U.S.A. and in this country where the, then, Civil Engineering Research Association sponsored work by the Cement and Concrete Association on statically applied loading and by the Building Research Station on fatigue loading.

The first results of this work, on static loading producing uniform bending, have now been published. ${ }^{(2,3)}$
They are of particular interest in that a number of parameters, previously accepted as being of significance, have been shown to be of little significance, and in that they are consistent with the assumption that bond between the steel and concrete does not break down; hence the width of the cracks is zero at the steel-concrete interface. These findings are in accord with those of more recent American research. ${ }^{(4)}$

Although further research on cracking is necessary to cover the various conditions met in practice, it is now possible to give some guidance in future codes of practice on the subject of crack control.

No doubt the C.E.B. commission and others will be making a critical appraisal of the data available from the tests carried out recently and, in particular, will be reconsidering the implications in regard to the significance of cracking for the corrosion of the reinforcing steel.

\section{REFERENCES}

1. COMITE EUROPEEN DU BETON. Recommendations for an international code of practice for reinforced concrete. London, American Concrete Institute and Cement and Concrete Association, 1964. pp. 156.

2. BASE, G. D., READ, J. B., BEeBY, A. W. and TAYLOR, H. P. J. Crack control in concrete beams. A comparison of high tensile and mild steel reinforcement. London, Civil Engineering Research Association, December 1966. pp. 74. Research Report 6. (Circulation restricted.)

3. BASE, G. D., READ, J. B., BEEBY, A. W. and TAYLOR, H. P. J. An investigation of the crack control characteristics of various types of bar in reinforced concrete beams. London, Cement and Concrete Association, 1967. Research Report 18. Part 1: pp. 44. Supplement: pp. 36. Part 2: pp. 31.

4. BROMS, в. B. Crack width and crack spacing in reinforced concrete members. Journal of the American Concrete Institute. Proceedings Vol. 62, No. 10. October 1965. pp. 12371256. 